\author{
7일령 조기 이유자돈에 대한 액상사료 자동급이기 이용효과 \\ 유용희* · 정일병* . 장병귀* · 문홍길* · 김태일* - 한정대* . 박홍석** \\ 농촌진흥청 축산기술연구소*, 전북대학교**
}

\title{
Studies on the Efficacy of the Newly Developed Automatic Liquid Feeder for 7-day Old Early Weaned Piglets
}

\author{
Y. H. Yoo*, I. B. Chung*, B. G. Jang*, H. K. Moon*, T. I. Kim* \\ J. D. Han* and H. S. Park** \\ National Livestock Research Institute, RDA*, Chonbuk National University**
}

\begin{abstract}
This study was conducted to test the efficacy of the automatic liquid feeder(designated as NLRI) developed by National Livestock Research Institute, Korea for 7-day old early-weaning piglets. The other automatic liquid feeder imported from USA(designated as IALF) was used for a comparative purpose. A total of sixty piglets of 7 days of age were allotted to three treatments. The control group of 20 piglets was raised by their own sows until 21 days of age, while others were shifted to automatic liquid feeders of either NLRI or IALF on 7 days of age and reared during 14 days post-weaning. After then, all the piglets were fed nutritionally identical mash diets until 70 days of age. Compared with control group, body weight of piglets reared on automatic liquid feeders were lighter $(l<0.05)$ at 21 days of age [5.55kg (control) vs 4.97 (NLRI) and 4.98kg (IALF)], while heavier $(K<0.05)$ at 70 days of age $(24.82 \mathrm{~kg}$ vs 30.17 and $29.42 \mathrm{~kg})$. The results indicated that pigs reared on liquid feeding showed higher $(<<0.05)$ average daily gain than control pigs during the whole experimental period [346.7g (control) vs 425.8 (NLRI) and 416.1g (IALF)], while no difference was found in feed/gain (1.67 vs 1.78 and 1.84). There was no difference in growth performance and incidence of diarrhea between two automatic liquid feeders, NLRI and IALF. Compared with control group, intestinal villi tended to be shorter in liquid feeding group during the first week, but were recovered within two weeks. The results suggest that the automatic liquid feeder newly developed by National Livestock Research Institute, Korea can be successfully used for rearing young piglets weaned at very early age.
\end{abstract}

(Key words : Automatic liquid feeder, Early weaned piglet, Growth performance, Villi height)

\section{I 서 론}

오늘날 국내 자돈 이유 일령은 일반적으로 21일령 전후에 주로 실시하고 있으나 양돈기술 의 발달로 인해 점차 단축되고 있는 추세이다. 또한 모돈으로 부터 오는 질병의 수직 감염 차
단과 청정종돈 생산을 위해 10 일령 이전에 실 시하는 조기이유 방식이 종돈장에서 점차 보급 이 시도되고 있다. 조기이유를 실시하고자 하 는 농가들은 액상사료를 인공급여 하고자 한 다. 그러나, 조기이유 자돈의 사육 문제점으로 는 이유 스트레스, 성장 장애, 사료섭취량 감

Corresponding author : Y. H. Yoo, National Livestock Research Institute, RDA, Tel : 031-290-1714, Fax : 031-290-1731, E-mail : yooyh@rda.go.kr 
소, 설사발생(Leibbrandt와 Ewan 1972; Lecce 등, 1979; Armstrong과 Clawson 1980) 등이 있고, 심리적으로는 어미로부터 격리되는 스트레스, 새로운 주위환경으로 재편성, 이유 후 어미젖 으로 부터 고체(가루)사료의 전환으로 인한 영 양적인 스트레스가 발생되며, 이유 후 7 1일 까지 사료섭취량이 낮아지고 이유 후 성장정체 가 있다고 보고하였다(Smith와 Lucas, 1956). 또 한, 분만모돈은 포유자돈에게 생후 1 일령 부터 6 주령까지 1 일 평균 50 분 간격으로 포유시키고 있다고(Hartman 등, 1962) 보고하였다. 따라서, 모돈의 포육 행동과 같이 조기이유 자돈을 인 공적으로 포유시키기 위해 인력에 의존하게 되 는 경우 매일 일정한 시간마다 액상사료를 제 조, 급이하는 작업이 곤란하게 된다. 이로 인해 조기이유의 효과를 충분히 달성하지 못하게 되 어 이유 자돈의 성장이 위축되는 문제점을 갖 게 된다. 이에 대해 액상사료 자동급이기를 이 용한 Lecce(1969)는 자돈 폐사의 감소, 허약자 돈 등의 인공사육 가능성을 보고하였다. 또한, Lecce 등(1979)은 액상사료 자동급이 장치로 매 시간 액상사료 급여 후 30 일령에 가루사료로 급격하게 전환하여도 증체율의 감소없이 사료 에 대한 스트레스를 최소화 할 수 있다고 보고 하였다. 따라서, 본 시험의 연구목적은 축산기 술연구소에서 개발한 액상사료 자동급이기를 이용하여 14 일령 이유자돈의 사육 가능성을 확 증하였는 바(유용희 등, 2001a), 7일령 조기이유 자돈에게도 액상사료 자동급이기를 이용 인공 사육 가능성을 살펴 보고자 실시하였다.

\section{재료 및 방법}

\section{1. 시험설계}

Table 1에서 보는 바와 같이 대조구는 생후 1 일령 부터 21일령 까지 모돈으로 부터 포유를 하였다. 처리구는 7일까지 모돈으로 부터 포유 를 한 후 이유를 실시하였다. 축산기술연구소 에서 개발한 액상사료 자동급이기(NLRI)와 수 입하여 이용되고 있는 액상사료 자동급이기 (IALF)를 이용 액상사료를 급여하여 서로 비교
Table 1. Experimental design

\begin{tabular}{cccc}
\hline Days of age & Control & NLRI $^{1)}$ & IALF $^{2}$ \\
\hline \hline $1 \sim$ & S-R $^{3)}$ & S-R & S-R \\
\hline $7 \sim$ L & S-R & A-R & A-R \\
\hline $21 \sim$ ) & \multicolumn{3}{c}{ Phase-feeding } \\
\hline
\end{tabular}

$\mathrm{NLRI}^{1)}$ : Automatic liquid feeder developed by National Livestock Research Institute

IALF $^{2)}$ : Imported Automatic Liquid Feeder

$S-R^{3)}$ : Sow-rearing

A- $\mathrm{R}^{4)}$ : Automatic liquid feeder-rearing

함과 동시에 모돈으로 부터 포유하는 자돈과 비교하였다. 그후 21일령 부터 70일령 까지 모 든 처리구는 동일한 가루사료를 단계별로 무제 한 급여하면서 총 63 일 동안 사양시험을 수행 하였다.

\section{2. 시험장소 및 공시동물}

본 시험은 충북 음성군 삼성면 소재 $\mathrm{D}$ 농장 에서 실시하였다. 시험에 사용된 공시자돈은 삼원교잡종(Landrace×Yorkshire×Duroc)이었다. 공시두수는 각 처리별 20 두 총 60 두 이었다. 돈방의 크기는 가로 $2.1 \mathrm{~m} \times$ 세로 $1.6 \mathrm{~m}$ 로 직사 각형이며, 돈방당 크기는 $3.36 \mathrm{~m}^{2}$ 로 4 개의 돈방 으로 구성되었다. 시험자돈은 2 산차 모돈 6 두에서 각각 복당 포유두수가 9 )두인 포 유자돈에서 선발하였다. 선발시 포유자돈은 비 슷한 체중을 고려하여 선발하였다.

\section{3. 시험사료}

시험사료는 Table 2에서 보는바와 같이 액상 사료는 이유후 14 일 동안 급여 후, 1 단계 사료 를 2주간, 2 단계 사료를 3주간 급여 후 마지막 2 주 동안 3 단계 사료를 급여하였다. 시험사료 중 옥수수는 분쇄옥수수를 이용하였다. 대두박 과 어분의 조단백질 함량은 각각 43\% \% 이었다. 대용유 원료사료 함량은 조단백질 25.0\% $\%$ 조섬유 $5.0 \%$ 칼슘 $0.8 \% \quad \%$ 비타민A $25,000 \mathrm{IU} / \mathrm{kg}$, 비타민 $\mathrm{D}_{3} 3,000 \mathrm{IU} / \mathrm{kg}$ 비타민 $\mathrm{B}$ 군 $60 \mathrm{mg} / \mathrm{kg}$, 테트 라싸이클린 $10 \mathrm{mg} / \mathrm{kg}$ 이었다. 
Table 2. Formula and chemical compositions of experimental diet

\begin{tabular}{|c|c|c|c|c|}
\hline Item & Liquid diet & Phase I & Phase П & PhaseIII \\
\hline \multicolumn{5}{|l|}{ Ingredients(\%) } \\
\hline Whole milk & 70.24 & - & - & - \\
\hline Corn & - & 47.30 & 59.22 & 66.35 \\
\hline Soy bean flour & - & 13.00 & 19.00 & - \\
\hline Soy bean meal & - & - & - & 17.45 \\
\hline Dried skim milk & 9.68 & - & - & - \\
\hline Dried whey & 3.23 & 20.00 & 10.00 & - \\
\hline Milk replacer & - & - & - & 10.80 \\
\hline Lactose & 1.08 & - & - & - \\
\hline Spray dried porcine plasma & 8.06 & 10.00 & - & - \\
\hline Soy protein concentrate & - & - & 5.00 & - \\
\hline Soy oil & - & 6.00 & 3.20 & - \\
\hline Fish meal & - & - & - & 3.20 \\
\hline Casein & 2.69 & - & - & - \\
\hline L-lysine HCL & - & 0.23 & 0.10 & 0.15 \\
\hline L-methionine & - & 0.15 & 0.15 & - \\
\hline Limestone & - & 0.52 & 0.48 & 0.80 \\
\hline Dicalcium phosphate & - & 1.75 & 1.80 & 0.50 \\
\hline Salt & - & 0.30 & 0.30 & 0.25 \\
\hline Vitamin-mineral mix & $4.92^{1)}$ & $0.25^{2)}$ & $0.25^{2)}$ & $0.30^{2)}$ \\
\hline \multirow[t]{2}{*}{ Antibiotics } & $0.10^{3)}$ & $0.50^{4)}$ & $0.50^{4)}$ & $0.20^{4)}$ \\
\hline & 100.00 & 100.00 & 100.00 & 100.00 \\
\hline \multicolumn{5}{|l|}{ Chemical compositions ${ }^{5)}$} \\
\hline ME(Kcal/kg) & 4,205 & 3,348 & 3,316 & 3,278 \\
\hline Crude protein(\%) & 29.01 & 20.21 & 19.17 & 18.03 \\
\hline Lysine(\%) & 2.37 & 1.47 & 1.20 & 1.01 \\
\hline Methionine(\%) & 0.61 & 0.35 & 0.41 & 0.28 \\
\hline Calcium(\%) & 0.85 & 0.91 & 0.85 & 0.60 \\
\hline Phosphorus(\%) & 0.67 & 0.68 & 0.71 & 0.49 \\
\hline \multicolumn{5}{|c|}{ 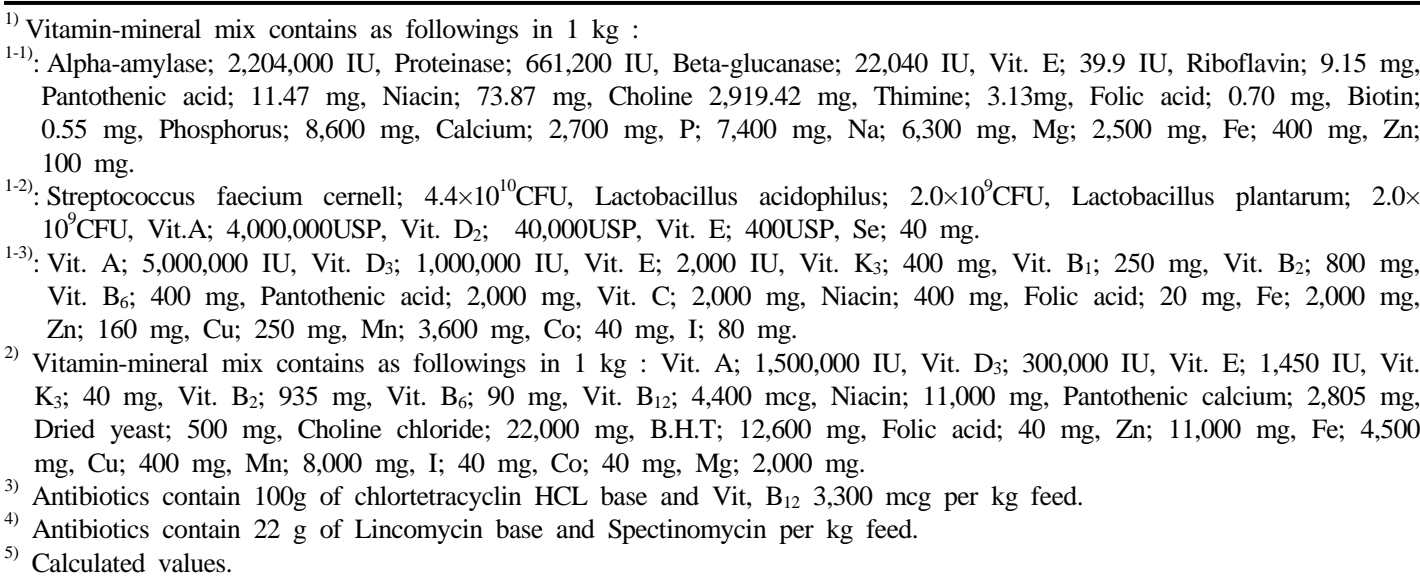 } \\
\hline
\end{tabular}




\section{4. 사양관리}

시험자돈은 온도와 환기가 자동 조절되는 무 창 자돈사에 입식하기 전에 돈사를 훈증소독 후 사육하였다. 액상사료의 물과 가루사료 혼 합비율은 액상사료 자동급이 장치를 이용할 경 우에(McCallum 등, 1977; Coalson과 Lecce, 1973; Jones 등, 1977)이 5:1로 혼합하여 급여하였다 는 보고에 기준 하였다. 시험기간중 물은 브랏 켙트가 달린 니플급수기를 설치 자유로이 음수 토록 하였고, 설치높이는 자돈의 어깨를 기준 하여 성장에 따라 높이를 조절해 주었다. 시험 개시시(7일령)부터 21일령 까지는 전해질제를 물에 희석한 후 포유자돈용 급이기를 이용하여 음수 시켰다. 2주일 동안 개발한 액상사료 자 동급이기(NLRI)의 액상사료 급여횟수는 임의로 기준을 설정하였다. 이유당일에는 액상사료에 대한 섭취관심이 없고 어미를 찾는 소리를 지 르며, 돈방 내를 서성거리는 행동을 보이며 액 상사료를 섭취하지 않아 급여하지 않았다. 시 험개시 2일째 6회, 이유 3일째 8회, 이유 4일째 10 회, 이유 6일째부터 7일째까지 12회로 이유 8일째부터 11일째까지 14회씩 증가 급여하고, 이유 12일째 12회, 이유 13일째 10회, 이유 14 일째 6회 등 점진적으로 감소 급여하고자 하였 다. 그러나, 이유 3 일째부터 자돈의 설사가 발 생하여 급여횟수를 조절하였다. 따라서, 급여횟 수는 이유 2일째 6회, 이유 3일째 8회, 이유 4 일째 6회, 이유 5일째 7회, 이유 6일째 10회, 이유 7일째 12회, 이유 8일 2일까지 14회, 이 유 13일째 10회, 이유 14일째 6회 급여하였다. 가루사료에 대한 적응을 위해 사료 무게를 계 량하여 이유 9일째(15일령)부터 Liquid diet 와 phase I 뇨를 5:5 비율로 혼합 가루사료를 조 제하여 입질사료로 소량 급여하기 시작하였다. 그 이후 이유 12 일째(18일령)는 1단계 사료로 변경하여 소량 급여하였다. 액상사료 자동급이 기는 1 일 1 회 교반조와 액상사료 이송라인을 세척하였다. 공시자돈 중 액상사료 급여 자돈 에게 출생당일, 생후 2일령, 5일령, 이유당일에 항생제(Naxcel : The Upjohn Company. Kalamazoo, MI 49001, USA)를 궁둥이 부위 근육내에 주사
하였다. 기타 방역관리는 농장의 관행에 준하 였다.

\section{5. 개발 액상사료 자동급이기의 특징}

액상사료 자동급이기는(NLRI) 물가열 및 배 출부(A), 가루사료 저장 및 배출부(B), 혼합 및 액상사료 제조부(C), 액상사료 이송부(D), 중앙 제어부(E)로 구성된 축산기술연구소에서 개발 한 Fig. 1을 이용하였다(유용희 등, 2001b).

액상사료 자동급이기는(NLRI) 크기는 가로 $(125 \mathrm{~cm}) \times$ 세로 $(51.5 \mathrm{~cm}) \times$ 높이 $(128 \mathrm{~cm})$ 로 제작되 었다.

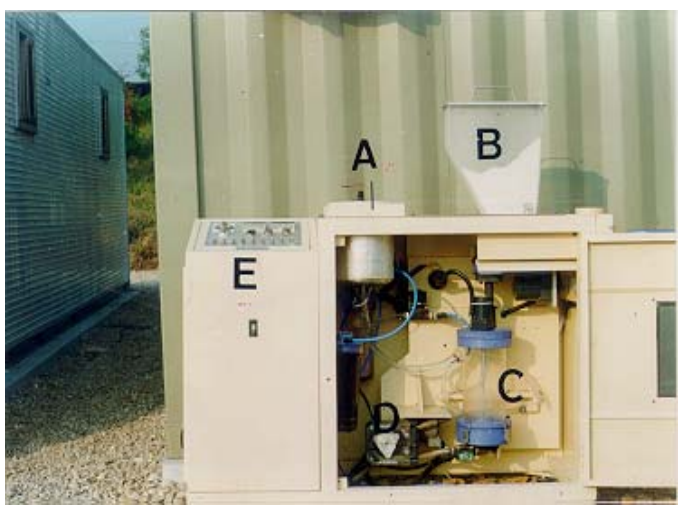

Fig. 1. The prototype of the automatic liquid feeder(NLRI).

\section{6. 조사항목 및 방법}

(1) 체중

시험에 공시된 자돈은 전자저울을 이용하여 시험 개시시와 종료시 2회 체중을 측정 평균하 여 개시 및 종료체중으로 하였다. 시험기간 중 에는 일주일 간격으로 체중변화를 조사하였다.

(2) 사료 섭취량

사료 섭취량은 시험 개시시부터 시험 종료시 까지 단계별 사료변경시 급이기에 남아있는 사 료의 잔량을 전부 수거하여 전자저울을 이용 무게를 칭량 후 총 급여량에서 칭량 된 잔량의 무게를 공제하여 실제 사료 섭취량으로 하였 다. 
(3) 설사발생

설사발생은 시험 전기간 동안 매일 오전 9시 부터 10 시까지 개체별로 설사발생을 조사하였 다. 조사기준은 Lecce 등(1985)의 설사발생 조 사시 기준에 의거 매일 정상 변을 배설하는 자 돈은 1점, 약간 묽은 변을 배설하는 자돈은 2 점, 거의 액체상태의 수양성 변을 배설하는 자 돈을 3점으로 구분 조사하였다.

\section{(4) 소장의 융모 변화}

십이지장, 공장, 회장의 융모 변화를 알아보 기 위하여 시험개시 직전(생후 7일령) 3 두, 개 시후 10 일령, 14 일령, 21 일령, 28일령에 처리별 로 3 두씩 총 27 두를 도살하였다. 도살 즉시 개 복하여 십이지장 기시부로 부터 10 $\mathrm{j} \mathrm{cm}$ 부 위와 공장 중간부위, 회장 말단부로 부터 $15 \mathrm{~cm}$ 상단부 조직을 각각 $3 \mathrm{~cm}$ 정도 채취하여 $10 \%$ 중성 포르마린으로 고정하였다. 일반조직표본 제작과정에 의해서 Paraffin에 포매한 조직을 조직절편기로 5 $\mu \mathrm{m}$ 두께의 연속절편을 제 작하여 일반적인 형태의 변화를 관찰하기 위하 여 Hematoxylin and Eosin(H \& E)으로 염색을 실시하고 광학 현미경(Leica Microsystems AG, Ernst-Leitz-Strasse 17-37, Germany, DMRBE)을 이용 40 배율로 융모의 높이를 관찰하였다.

\section{(5) 통계분석}

시험성적의 통계 분석은 SAS(1994) 통계 Package의 General Linear Models를 이용 처리간 유 의성 검정을 위하여 DUNCAN의 다중비교와 t-test 를 실시하였다.

\section{III 결과 및 고찰}

\section{1. 일당증체량 및 사료섭취량과 사료요구율}

개발된 액상사료 자동급이기(NLRI)를 이용 액상사료를 자동조제 인공 급여한 시험자돈과 모돈으로 부터 포유한 자돈의 체중, 일당증체 량, 일일 두당 사료섭취량, 사료요구율의 변화 는 Table 3 에서 보는바와 같다. 모돈으로 부터 포유한 자돈의 체중은 $2.96 \mathrm{~kg}$ (시험개시시), 21 일
령 $5.55 \mathrm{~kg}$ 이었다. 액상사료 자동급이기(NLRI) 로 인공급여 자돈은 $3.17 \mathrm{~kg}$ (시험개시시), 21일령 $4.97 \mathrm{~kg}$ 으로 모돈으로 부터 포유한 자돈보다 21 일령 체중대비 9.3\% 적었다(I<0.05). 그 후 21 일령에 이유를 실시한 후 모돈으로 부터 포유 한 자돈의 체중보다 액상사료 인공급여 자돈은 70 일령에 $21.5 \%$ 더 체중이 증가됨을 보였다 (I<0.05). 일당증체량은 액상사료를 인공급여 (NLRI)시 7일령 부터 14일령 까지는 모돈으로 부터 포유한 자돈보다 유의적으로 증체가 적었 다(I<0.05). 14일령 부터 21일령 까지는 차이 를 보이지 않았고, 21일령 부터 56일령 까지는 모돈으로 부터 포유한 자돈보다 유의적으로 높 은 일당증체를 보였다 $(\mathrm{I}<0.05)$. 그 후 56 일령 부터 70 일령 까지 2 주 동안은 처리간에 차이를 보이지 않았다. 시험 전기간은 액상사료 인공 급여 자돈이 모돈으로 부터 포유한 자돈보다 $22.8 \%$ 더 높았다(I<0.05). 그리고, 개발한 액상 사료 자동급이기(NLRI)와 수입기(IALF)를 비교 한 결과 처리간에 유의적인 차이를 보이지 않 았다. 두당 일일 액상사료 섭취량은(NLRI) 7일 령부터 21일령까지 1 일 $115 \mathrm{~g}$ 이었다. 시험 전 기간 모돈으로 부터 포유한 자돈의 경우 두당 일일 751g, 액상사료 인공급여(NLRI) 자돈은 $761 \mathrm{~g}$ 으로 모돈으로 부터 포유한 자돈보다 액상 사료 인공급여 자돈이 약간 많았다. 사료요구 율은 액상사료 인공급여시(NLRI) 7일령부터 21 일령까지 0.95 이었다. 시험 전기간 모돈으로 부터 포유한 자돈의 경우 1.67 이었으나, 액상 사료 인공급여(NLRI) 자돈은 1.78 이었다. 새로 이 개발한 액상사료 자동급이기(NLRI)와 수입 한 액상사료 자동급이기(IALF)의 처리간에는 차이는 없었다.

이상 일당증체량, 사료섭취량, 그리고 사료 요구율 결과를 종합하여 볼 때, 이유초기에는 성장이 낮아지나 Table 3 에서 보는 것처럼 그 후 계속적으로 시험종료시 까지 성장이 높아지 는 것으로 나타나고 있다. 이러한 결과는 이유 일령, 급여기간, 급여방식 등은 다르나 Pond 등 (1971)의 2일령에 이유하여 액상사료를 21일령 까지 급여한 결과, 평균 일당증체는 $66 \mathrm{~g} \sim \mathrm{Jg}$, 사료요구율은 0.69 74이었다고 보고하였다. 
Table 3. The growth performance of piglets raised by sows or automatic liquid feeders(NLRI or $(\mathrm{ALF})^{1)}$

\begin{tabular}{|c|c|c|c|}
\hline \multirow{2}{*}{ Item } & \multicolumn{3}{|c|}{ Treatment $^{2)}$} \\
\hline & Control & NLRI & IALF \\
\hline \multicolumn{4}{|l|}{ Body weight(g/head) } \\
\hline Initial(7d of age) & $2,960 \pm 0.07$ & $3,170 \pm 0.09$ & $3,170 \pm 0.10$ \\
\hline $14 d$ & $4,360^{\mathrm{a}} \pm 0.12$ & $3,760^{\mathrm{b}} \pm 0.10$ & $3,810^{b} \pm 0.14$ \\
\hline 21d & $5,550^{\mathrm{a}} \pm 0.11$ & $4,970^{\mathrm{b}} \pm 0.15$ & $4,980^{\mathrm{b}} \pm 0.21$ \\
\hline $35 d$ & $8,520^{\mathrm{a}} \pm 0.35$ & $10,740^{\mathrm{b}} \pm 0.31$ & $10,810^{\mathrm{b}} \pm 0.46$ \\
\hline $56 \mathrm{~d}$ & $14,940^{\mathrm{a}} \pm 0.63$ & $19,620 \pm 0.60$ & $18,750^{\mathrm{b}} \pm 0.72$ \\
\hline Final (70d) & $24,820^{\mathrm{a}} \pm 0.73$ & $30,170^{\mathrm{b}} \pm 0.64$ & $29,420^{\mathrm{b}} \pm 1.01$ \\
\hline \multicolumn{4}{|c|}{ Average daily gain(g/head) } \\
\hline Initial fd & $200^{\mathrm{a}} \pm 0.01$ & $72^{\mathrm{b}} \pm 0.00$ & $91^{\mathrm{b}} \pm 0.00$ \\
\hline $14 \mathrm{~d}$ to $21 \mathrm{~d}$ & $170 \pm 0.01$ & $172 \pm 0.01$ & $167 \pm 0.01$ \\
\hline $21 \mathrm{~d}$ to $35 \mathrm{~d}$ & $211^{\mathrm{a}} \pm 0.02$ & $406^{\mathrm{b}} \pm 0.01$ & $412^{\mathrm{b}} \pm 0.02$ \\
\hline $35 \mathrm{~d}$ to $56 \mathrm{~d}$ & $306^{\mathrm{a}} \pm 0.01$ & $423^{b} \pm 0.02$ & $378^{\mathrm{b}} \pm 0.02$ \\
\hline $56 \mathrm{~d}$ to $70 \mathrm{~d}$ & $706 \pm 0.01$ & $754 \pm 0.01$ & $762 \pm 0.03$ \\
\hline Overall & $347^{\mathrm{a}} \pm 0.01$ & $426^{\mathrm{b}} \pm 0.00$ & $416^{b} \pm 0.01$ \\
\hline \multicolumn{4}{|c|}{ Daily feed intake(g/head) } \\
\hline Initial Id & - & 115 & 120 \\
\hline $21 \mathrm{~d}$ to $35 \mathrm{~d}$ & $427^{\mathrm{a}} \pm 6.00$ & $635^{b} \pm 8.00$ & $672^{c} \pm 8.00$ \\
\hline $35 d$ to $56 \mathrm{~d}$ & $600^{\mathrm{a}} \pm 10.00$ & $861^{\mathrm{b}} \pm 15.00$ & $855^{\mathrm{b}} \pm 12.00$ \\
\hline $56 \mathrm{~d}$ to $70 \mathrm{~d}$ & $1,277^{\mathrm{a}} \pm 2.00$ & $1,383^{\mathrm{b}} \pm 9.00$ & $1,370^{\mathrm{b}} \pm 4.00$ \\
\hline Overall & 751 & 761 & 763 \\
\hline \multicolumn{4}{|l|}{ Feed/Gain } \\
\hline Initial Id & - & 0.95 & 0.93 \\
\hline $21 \mathrm{~d}$ to $35 \mathrm{~d}$ & $2.02^{\mathrm{a}} \pm 0.09$ & $1.58^{\mathrm{b}} \pm 0.11$ & $1.63^{\mathrm{b}} \pm 0.04$ \\
\hline $35 d$ to $56 d$ & $1.96 \pm 0.18$ & $2.03 \pm 0.07$ & $2.26 \pm 0.04$ \\
\hline $56 \mathrm{~d}$ to $70 \mathrm{~d}$ & $1.80 \pm 0.01$ & $1.83 \pm 0.04$ & $1.78 \pm 0.01$ \\
\hline Overall & 1.67 & 1.78 & 1.84 \\
\hline
\end{tabular}

${ }^{1)}$ Values are mean $\pm \mathrm{SE}$.

2) See Table 1.

a,b,c, Means with different superscripts in the same row are significantly different( $(<0.05)$.

Haye와 Kornegy(1979)은 어미 포유와 12시간 포유후 액상사료 자동급이기를 이용하여 30 일 동안 인공사육한 결과 평균 일당증체에서 서로 차이가 없었으나, 인공사육 자돈이 초기 10 일 동안 유의적( $<$ < 0.05$)$ 으로 적었다 보고하였다. 모돈으로 부터 포유한 자돈의 경우 Barber 등 (1955)은 생후 28일령 까지 일당증체는 대략 $175 \mathrm{~g}$ 이었다는 보고와 본 연구와 같은 경향이 었다. Brooks(1998)는 액상사료 급여가 성장률
이 유의적으로 높은 원인은 액상사료 섭취량이 매우 높기 때문이라는 보고와도 같은 경향이었 다. Odle 과 Harrell(1998)은 액상사료는 이유초 기에 성장률과 사료섭취량을 증가시킬 수 있다 하였다. Zijlstra 등(1996)도 액상사료 급여 자돈 의 1 주일 후 체중이 모돈으로 부터 포유한 자 돈보다 성장률이 $20 \%$ 더 높았다고( $<<0.001)$ 보고하였다. 그러나, Rodriguez와 Young(1981)은 유제품을 액상사료로 급여시 모유 포유보다는 
증체가 떨어진다 보고하였다. Braude와 Newport (1977)는 2일령 자돈을 액상사료 급여와 사양방 법에 따라 체중변화, 사료섭취량, 사료요구율을 비교한 결과, 초기성장에는 유의적인 차이가 있었으나 56일령 까지 비교시 처리간에 차이가 없다. Wilson과 Leibholz(1981)은 7일령에 이유 한 자돈을 35일령 까지 액상 또는 펠렛으로 급 여시 체중 증가에는 유의적인 차이가 없다는 보고와는 다른 경향이었다.

\section{2. 설사발생}

수입한 액상사료 자동급이기(IALF)와 새로이 개발한 액상사료 자동급이기(NLRI)를 이용 액 상사료를 자동조제 인공급여 할 때 설사발생 두수에 대하여 비교 조사하였다. 이유 후 액상 사료 급여시 Table 4에서 보는바와 같이 처리 간에 차이를 보이지 않았다. 이것은 개발한 액 상사료 자동급이기(NLRI)는 사용상 문제는 적 은 것으로 사료되었다. 설사발생 시기는 Fig. 2 에서 보는 것처럼 이유 후 3 일부터 14일까지 12 일 동안 발생하였다. 설사발생에 따른 폐사 자돈은 없었다. 액상사료를 인공 급여한 결과, Weybrew 등(1949)과 Lecce 등(1985)는 액상사료 를 급여시 초기 수일동안 많은 자돈들이 황색 의 설사가 발생하였다는 보고와 Braude 등 (1970)은 액상사료를 적당하게 급여시 폐사율이 낮았으며, 액상사료내 고형분이 $12.5 \%$ 함유한 우유나 대용유를 매시간 급여시 높은 설사발생 빈도를 보였으나 자돈 폐사는 없었다는 보고와

Table 4. Incidence of diarrhea in piglets weaned at 7 days of age and raised using the NLRI or IALF $^{1)}$

\begin{tabular}{lcc}
\hline \multirow{2}{*}{ Item } & \multicolumn{2}{c}{ Treatment $^{2)}$} \\
\cline { 2 - 3 } & NLRI & IALF \\
\hline \hline Normal feces & 497 & 512 \\
Mild feces & 34 & 18 \\
Watery feces & 36 & 33 \\
\hline
\end{tabular}

\footnotetext{
${ }^{1)}$ Values are the sum of(No. of piglets of each diarrhea score $\times$ relevant diarrhea score) during the examining period.
}

${ }^{2)}$ See Table 1.

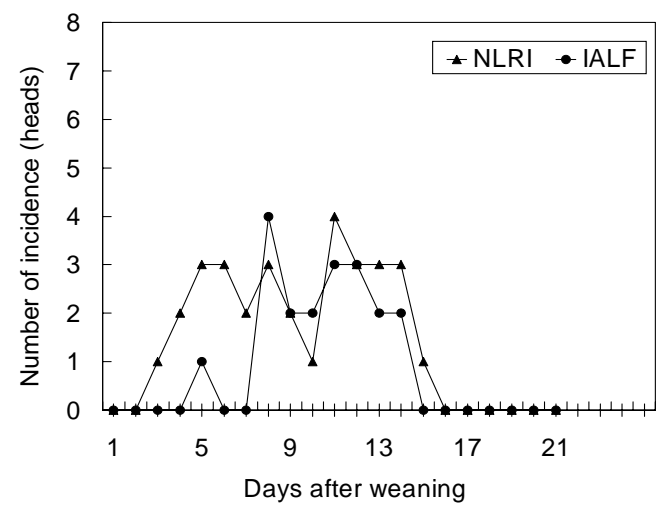

Fig. 2. Incidence of diarrhea in piglets weaned at 7 days of age and raised using the NLRI or IALF.

본 연구 결과는 이유일령은 다르나 같은 경향 을 보였다. 그러나, Catron 등(1953)과, White 등 (1969)은 인공사육시 설사와 높은 폐사율이 발 생했다는 보고와는 다른 경향을 보였다.

\section{3. 소장 융모의 변화}

액상사료 자동급이기를 이용 액상사료를 인 공 급여한 자돈의 일령별 십이지장, 공장, 회장 의 융모 변화를 모돈으로 부터 포유한 자돈과 비교하였다. Table 5에서 보는 바와 같이 처리 간 통계적 유의차는 없었으나, 십이지장 융모 높이는 모돈으로 부터 포유한 자돈보다 이유후 3 일 동안 액상사료를 인공 급여한 자돈의 융모 높이가 $18 \%$ 정도 낮았다. 그러나, 액상사료를 인공 급여한 자돈은 7일째(14일령)부터 회복되 는 것으로 나타났다. 공장 융모 높이는 모돈으 로 부터 포유한 자돈보다 액상사료를 인공 급

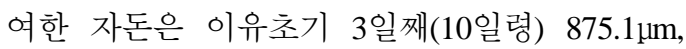
7일째(14일령) $544.7 \mu \mathrm{m}$ 으로 $31 \%, 58.5 \%$ 낮아 졌다가 액상사료 인공급여 14일째(21일령) 부 터 융모가 회복되는 것으로 나타났다. 회장의 융모 높이는 처리간에 어떠한 경향을 보이지 않았다. 이러한 결과는 Toplis와 Tibble(1995)는 조기이유 자돈에게 액상사료 급여시 장의 손 상을 극복할 수 있다고 보고와 같은 경향을 보였다. 
Table 5. Villus height of duodenum, jejunum and ileum of piglets raised by sows or automatic liquid feeder after weaning at 7 days of age ${ }^{1)}$

\begin{tabular}{|c|c|c|c|c|c|c|}
\hline \multirow{2}{*}{ Item } & \multicolumn{2}{|c|}{ Duodenum( $(\mu \mathrm{m})$} & \multicolumn{2}{|c|}{ Jejunum(jm) } & \multicolumn{2}{|c|}{ Ileum(1um) } \\
\hline & Control & $A-R$ & Control & $A-R$ & Control & $A-R$ \\
\hline $\begin{array}{l}\text { Initia1 } \\
\text { (7d of age) }\end{array}$ & $973.7 \pm 94.03$ & $973.7 \pm 94.03$ & $1021.3 \pm 48.89$ & $1021.3 \pm 48.89$ & $819.1 \pm 47.96$ & $819.1 \pm 47.96$ \\
\hline $\begin{array}{l}\text { D3 } \\
\text { (10d of age) }\end{array}$ & $1115.3 \pm 27.26$ & $914.4 \pm 79.37$ & $1268.2 \pm 76.91$ & $875.1 \pm 59.10$ & $743.1 \pm 72.90$ & $751.4 \pm 51.47$ \\
\hline $\begin{array}{l}\text { D7 } \\
\text { (14d of age) }\end{array}$ & $1019.4 \pm 41.39$ & $1020.2 \pm 86.31$ & $1315.1 \pm 30.89$ & $544.7 \pm 35.51$ & $790.0 \pm 119.11$ & $487.7 \pm 66.60$ \\
\hline $\begin{array}{l}\text { D14 } \\
\text { (21d of age) }\end{array}$ & $674.2 \pm 34.53$ & $816.1 \pm 27.44$ & $487.9 \pm 31.36$ & $749.7 \pm 76.46$ & $550.3 \pm 45.87$ & $640.9 \pm 53.04$ \\
\hline $\begin{array}{l}\text { D21 } \\
\text { (28d of age) }\end{array}$ & $839.6 \pm 44.86$ & $1197.2 \pm 33.10$ & $477.9 \pm 47.41$ & $676.8 \pm 29.77$ & $663.9 \pm 49.77$ & $582.4 \pm 21.25$ \\
\hline
\end{tabular}

1) Values are mean \pm SE.

A-R : Automatic liquid feeder-rearing.

공장의 융모 성상을 모돈으로 부터 포유한 자돈과 일령별로 비교한 결과 Fig. 3에서 보 는 것처럼 액상사료 인공급여시 이유 1 주일 부터는 모돈으로 부터 포유한 자돈과 비교시 정상적으로 융모의 끝이 가늘고 길게 자라는 것을 보여주고 있다. 그러나 그 후 동일한 가 루사료를 급여 후 28일령 인공급여 자돈의 융모 모양은 융모가 가늘고 길게 자라는 것 을 볼 수 있으나, 모돈으로 부터 포유 후 21 일령에 이유하여 1 주일 동안 동일한 가루사 료를 섭취한 자돈은 액상사료를 섭취한 자돈 의 융모 모양보다 융모가 심하게 탈락되고 위축된 것으로 나타났다. 이것은 Table 5에서 본 융모 높이의 차이처럼 융모의 모양에서도 같은 경향이었다. 이상의 결과를 종합하여 볼 때, 액상사료 자동급이기를 이용 액상사료를 조제하여 급여할 때 초기의 성장은 어미로부 터 포유한 자돈보다 성장율이 낮은 결과를 보였다. 설사발생은 약 2주 동안 지속되었다. 소장의 융모 높이는 이유 후 1 주일까지는 낮 은 결과를 보였다. 그러나 이유 후 2주부터 성장율이 높아지고, 소장의 융모 높이도 회복 되었고, 설사는 발생되지 않았다. 따라서, 액 상사료 자동급이기를 이용 액상사료를 급여 함으로써 7일령 조기이유 자돈을 사육할 수 있을 것으로 사료된다.

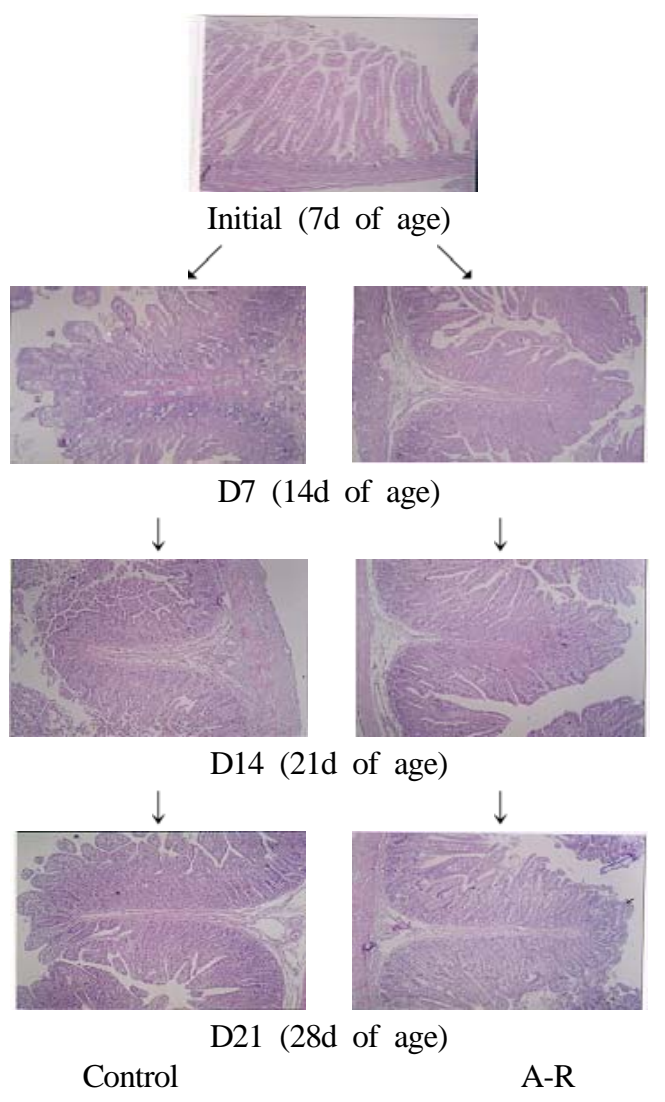

Fig. 3. Morphological changes of jejunal villi of piglets raised by sows or automatic liquid feeder(A-R) after weaning at 7 days of age. 


\section{IV 요 약}

축산기술연구소에서 개발한 액상사료 자동급 이기의 성능을 검사하고 이를 이용하여 조기 이유자돈의 사육 가능성을 알아보기 위하여 본 연구를 실시하였다. 포유중인 자돈 60 두를 공 시하여 대조구 자돈들은 21일령 까지 모돈에게 포유시켰다. 나머지는 생후 7일령에 모돈으로 부터 이유시킨 다음 액상사료 자동급이기를 이 용하여 21일령까지 액상사료를 자동으로 인공 급여 하였다. 그 이후 모든 자돈을 70 일령 까 지 단계적으로 같은 가루사료를 급여하였다. 그리고, 미국으로부터 수입되어 사용되고 있는 액상사료 자동급이기를 새로이 개발한 액상사 료 자동급이기와 비교하여 사용하였다. 자돈들 의 성장과 사료이용, 그리고 설사발생과 소장 의 융모 변화 등을 조사하였다. 그 결과는 다 음과 같다. 생후 7 일에 모돈으로 부터 이유한 다음 액상사료 자동급이기를 이용하여 액상사 료를 급여한 자돈들의 21일령 체중은 모두 포 유를 지속한 자돈들에 비해 모두 유의하게(I < 0.05) 낮았다(5.55 vs $4.97 \& 4.98 \mathrm{~kg} / \mathrm{head})$. 그 이후 액상사료 급여 자돈들의 성장이 빨라 70 일령에 이르러서는 체중이 모돈으로 부터 포유 하였던 자돈들에 비해 오히려 유의적으로(I < $0.05)$ 증가하는 결과를 보여 주었다(24.82 vs. $30.17 \& 29.42 \mathrm{~kg} / \mathrm{head})$. 시험 전기간 동안의 일 당증체량은(346.7 vs 425.8 \& 416.1g/head) 모돈 으로 부터 포유한 자돈보다 인공 포유 자돈들 이 유의하게 증가하였다(I<0.05). 사료요구율 은 시험 전기간 동안 차이가 없었다 $(1.67 \mathrm{vs}$ 1.78 and 1.84). 자돈들의 설사발생 빈도에 있어 액상사료 자동급이기 간에 차이가 없었다. 소 장의 융모 변화를 비교한 결과 액상사료 인공 포유 3일째(10일령) 십이지장 융모 높이가 크게 낮아진 것으로 나타났으나 7일째(14일령) 부터 융모가 회복되는 것으로 나타났다. 공장의 융 모높이는 7일째(14일령) 크게 낮아진 것으로 나 타났으나 14일째(21일령) 부터 융모가 회복되는 것으로 나타났다. 회장의 융모 높이는 처리간 에 어떠한 경향을 보이지 않았다. 축산기술연 구소에서 개발한 액상사료 자동급이기(NLRI)와
수입한 액상사료 자동급이기(IALF)에서 자돈 성장의 차이는 보이지 않았다. 이상의 결과 새 로이 개발한 NLRI로 생후 7일만에 조기이유 시킨 자돈들도 성공적으로 육성할 수 있음을 보여주었다.

\section{$\mathrm{V}$ 인 용 문 헌}

1. Armstrong, W. D. and Clawson, A. J. 1980. Nutrition and management of early weaned pigs: effect of increased nutrient concentrations and (or) supplemental liquid feeding. J. Anim. Sci. 50:377.

2. Barber, R. S., Braude, R. and Mitchell, K. G. 1955. Studies on milk production of large white pigs. J. Agr. Sci. 46:97.

3. Braude, R., Mitchell, K. G., Newport, M. J. and Porter, J. W. G. 1970. Artificial rearing of pigs. 1. Effect of frequency and level of feeding on performance and digestion of milk proteins. Br. J. Nutr. 24:501.

4. Braude, R. and Newport, M. J. 1977. A note on a comparison of two systems for rearing pigs weaned at 2 days of age, involving either a liquid or a pelleted diet. Anim. Prod. 24:271.

5. Brooks, P. 1998. Realising the growth potential of newly weaned pigs. Pig Progress. P6.

6. Catron, D.V., Nelson, L. F., Ashton, G. C. and Maddock, H. M. 1953. Development of practical synthetic milk formulas for baby pigs. J. Anim. Sci. 12:62.

7. Coalson, J. A. and Lecce, J. G. 1973. Herd differences in the expression of fatal diarrhea in artificially reared piglets weaned after 12 hours vs. 36 hours of nursing. J. Anim. Sci. 36:1114.

8. Hartman, D. A., Ludwick, T. M. and Wilson, R. F. 1962. Certain aspects of lactation performance in sows. J. Ainm. Sci. 21:883.

9. Haye, S. N. and Kornegay, E. T. 1979. Immunoglobulin $\mathrm{G}$. A and $\mathrm{M}$ and antibody response in sow-reared and artificially-reared pigs. J. Anim. Sci. 48:1116.

10. Jones, E. E., Coalson, J. A. and Lecce, J. G. 1977. Soy flour as a source of protein for baby pigs. J. Anim. Sci. 45:1073.

11. Lecce, J. G. 1969. Rearing colostrum-free pigs in an automatic feeding device. J. Anim. Sci. 28:27.

12. Lecce, J. G., Armstrong, W. D., Crawford, P. C. and Ducharm, G. A. 1979. Nutrition and management of early weaned piglets: liquid vs dry feeding. J. Anim. Sci. 48:1007.

13. Lecce, J. G., Dorsey, W. E., Armstrong, W. D., Jones, E. E. and Linnerud, A. C. 1985. Liquid diets 
fed hourly to pigs weaned at 19 days of age and exposed to rotavirus(weanling diarrhea). J. Anim. Sci. 61:1043.

14. Leibbrandt, V. C. and Ewan, R. C. 1972. Effect of weaning and age at weaning on performance by baby pigs. J. Anim. Sci. 35:1107(Abstract).

15. McCallum, I. M., Owen, B. D. and Farmer, M. J. 1977. An automated nipple feeding system for artificially rearing colostrum-deprived neonatal piglets. Can. J. Anim. Sci. 57:489.

16. NRC. 1988. Nurtrient Requirements of Swine(9th ed.). National Academy Press, Washingtong, D. C.

17. Odle, J. and Harrell, R. J. 1998. Nutritional approaches for improving neonatal piglet performance : liquid diets for early-weaned pigs. The 8th world conference on animal production pre-conference symposia 8th WCAP(Seoul, Korea). P35.

18. Pond, W. G., Snyder, W., Walker, E. F., Stillings, Jr., B. R. and Sidwell, V. 1971. Comparative utilization of casein, fish protein concentrate and isolated soybean protein in liquid diets for growth of baby pigs. J. Anim. Sci. 33:587.

19. Rodriguez, J. P. and Young, L. G. 1981. Utilization of corn and wheat in diets of pigs weaned at 7 days of age. J. Anim. Sci. 53:683.

20. SAS. 1994. SAS user's guide statistics SAS. Inst. Inc. Cary. NC.

21. Smith, H. and Lucas, I. A. M. 1956. The early weaning of pigs. I The effect upon growth of variations in the protein, fat, sucrose, antibiotic, vitamin and mineral contents of diets for pigs of 8 25lbs. liveweight and a comparison of wet and dry feeding. J. Agr. Sci. 48:220.

22. Toplis, P. and Tibble, S. 1995. Animal psychology profits the very early weaned piglet. Pig-Misset. P 8.

23. Weybrew, J. A., Stewart, H. A., Matrone, G. and Peterson, W. J. 1949. Supplemented milk diets for young pigs in cages. J. Anim. Sci. 8:207.

24. White, F., Whenham, G., Sharman, G. A. M., Jones, A. S., Rattray, E. A. S. and McDonald, I. 1969. Stomach function in relation to a scour syndrome in the piglet. Brit. J. Nutr. 23:847.

25. Wilson, R. H. and Leibholz, J. 1981. Digestion in the between 7 and $35 \mathrm{~d}$ of age 1 . The performance of pigs given milk and soya-bean proteins. Br. J. Nutr. 45:301.

26. Zijlstra, R. T., Whang, K. Y., Easter, R. A. and Odle, J. 1996. Effect of feeding a milk replacer to early-weaned pigs on growth body composition and small intestinal morphology compared with suckled littermates. J. Anim. Sci. 74:2948.

27. 유용희, 정일병, 한정대, 장병귀, 이덕수, 박준철, 박홍석. 2001a. 액상사료 자동급이기를 이용한 포유자돈의 조기이유가 자돈 생산성에 미치는 영향. 한국동물자원과학회지. 43(4):587.

28. 유용희, 정일병, 한정대, 이덕수, 강희설, 최희철, 전병수, 박홍석. 2001b. 조기이유 자돈용 액상사 료 자동급이기 개발. 한국축산시설환경학회지. 7 (1): 1.

(접수일자 : 2003. 5. 30. / 채택일자 : 2003. 10. 15.) 